\title{
Analisis Pengaruh Bauran Pemasaran Jasa Terhadap Sale Pada Hotel Galuh Anindita Yogyakarta
}

\author{
Ajie Wicaksono \\ Akademi Pariwisata STIPARY Yogyakarta \\ Email : jiewic90@gmail.com
}

\begin{abstract}
Galuh Anindita Hotel is a non-star hotel located strategically in the center of Yogyakarta. As a non-star hotel located not far from the center of Yogyakarta tourism, of course the challenge is greater because they have to compete with other hotels, especially star hotels, so various efforts need to be made to get the expected sale. This study aims to determine the effect of marketing mix on sales at Galuh Anindita Hotel Yogyakarta. The method used in this research is quantitative descriptive by collecting data through questionnaires, observation, and documentation. The questionnaire was distributed to visitors of the Galuh Anindita Hotel in Yogyakarta during May-July 2019. Analysis of the data used was linear regression test. The instrument test using validity and reliability shows that all items are declared valid and reliable so that it can be used for calculation analysis. Based on the results of the correlation test it was concluded that the relationship between marketing mix and sale was categorized strong with a correlation value of 0.728 . Hypothesis testing shows that the marketing mix has a significant effect on sales as indicated by a probability value of $0,000(<0.05)$ and $t$ of 10.498. The magnitude of the effect of the marketing mix on sales was $52.9 \%$.
\end{abstract}

Keywords: marketing mix, sale, hotel

\begin{abstract}
Abstrak - Hotel Galuh Anindita adalah hotel non bintang yang berlokasi strategis di tengah kota Yogyakarta. Sebagai hotel non bintang yang terletak tidak jauh dari pusat pariwisata Yogyakarta, tentunya tantangan lebih besar karena harus bersaing dengan hotel lain terutama hotel berbintang sehingga berbagai upaya perlu dilakukan untuk mendapatkan sale yang diharapkan. Penelitian ini bertujuan untuk mengetahui pengaruh bauran pemasaran terhadap sale di Hotel Galuh Anindita Yogyakarta. Metode yang digunakan dalam penelitian ini yaitu deskriptif kuantitatif dengan pengumpulan data melalui angket, observasi, dan dokumentasi. Angket disebarkan kepada pengunjung Hotel Galuh Anindita Yogyakarta selama bulan Mei-Juli 2019. Analisis data yang digunakan yaitu dengan uji regresi linear. Uji instrumen dengan menggunakan validitas dan reliabilitas menunjukkan bahwa seluruh item dinyatakan valid dan reliabel sehingga dapat digunakan untuk analisis perhitungan. Berdasarkan hasil uji korelasi disimpulkan bahwa hubungan antara bauran pemasaran dengan sale dikategorikan kuat dengan nilai korelasi sebesar 0,728. Uji hipotesis menunjukkan bahwa bauran pemasaran berpengaruh secara signifikan terhadap sale yang ditunjukkan dengan nilai probabilitas sebesar 0,000 $(<0,05)$ dan t sebesar 10,498. Besarnya pengaruh bauran pemasaran terhadap sale sebesar $52,9 \%$.
\end{abstract}

Kata kunci: bauran pemasaran, sale, hotel

\subsection{Latar Belakang}

Usaha hotel di Yogyakarta semakin meningkat dari tahun ke tahun. Hal tersebut untuk memenuhi kebutuhan wisatawan yang juga semakin meningkat yang berkunjung ke Yogyakarta. Berdasarkan data dari Buku
Statistik Kepariwisataan selama 3 tahun terakhir yaitu 2015-2017, jumlah wisatawan terus menunjukkan kenaikan baik wisatawan domestik maupun mancanegara. Data kunjungan wisatawan tersebut dapat dilihat pada tabel berikut.

Tabel 1. Data Kunjungan Wisatawan DIY 2015-2017

\begin{tabular}{|l|c|c|c|r|r|r|}
\hline \multirow{2}{*}{ Tahun } & \multicolumn{3}{|c|}{ Wisatawan domestik (orang) } & \multicolumn{1}{c|}{ Wisatawan mancanegara (orang) } \\
\cline { 2 - 7 } & $\begin{array}{c}\text { Tahun } \\
\mathbf{2 0 1 5}\end{array}$ & $\begin{array}{c}\text { Tahun } \\
\mathbf{2 0 1 6}\end{array}$ & $\begin{array}{c}\text { Tahun } \\
\mathbf{2 0 1 7}\end{array}$ & $\begin{array}{c}\text { Tahun } \\
\mathbf{2 0 1 5}\end{array}$ & $\begin{array}{c}\text { Tahun } \\
\mathbf{2 0 1 6}\end{array}$ & \multicolumn{1}{c|}{$\begin{array}{c}\text { Tahun } \\
\mathbf{2 0 1 7}\end{array}$} \\
\hline Kota Yogyakarta & 5.388 .352 & 5.271 .471 & 5.049 .608 & 232.913 & 249.481 & 297.695 \\
\hline Kab. Sleman & 4.695 .740 & 5.439 .165 & 6.552 .487 & 255.194 & 246.136 & 262.071 \\
\hline Kab. Bantul & 4.763 .614 & 5.400 .260 & 9.130 .657 & 0 & 5.540 & 10.493 \\
\hline $\begin{array}{l}\text { Kab.Gunung } \\
\text { Kidul }\end{array}$ & 2.642 .759 & 3.476 .008 & 3.225 .929 & 5.319 & 3.882 & 21.067 \\
\hline Kab.Kulon Progo & 1.289 .672 & 1.346 .894 & 1.390 .331 & 23 & 6.506 & 10.455 \\
\hline
\end{tabular}




\begin{abstract}
\begin{tabular}{|l|l|l|l|l|l|l|} 
Jumlah & 19.266 .233 & 21.445 .343 & 25.950 .793 & 493.449 & 511.545 & 601.781 \\
\hline
\end{tabular}
Sumber: Buku Statistik Kepariwisataan DI Yogyakarta (2018), diakses dalam https://visitingjogja.com

Jumlah kunjungan wisatawan yang semakin meningkat tersebut dapat menjadi peluang yang menjanjikan bagi usaha perhotelan, baik hotel bintang maupun non bintang. Pada tahun 2015, jumlah Hotel Bintang di DIY yang bersertifikasi sebanyak 64 Hotel dengan jumlah kamar 5.478 yang terdiri dari intang 5 sebanyak 7 Hotel (jumlah kamar 1.518 buah), Bintang 4 sebanyak 16 Hotel (jumlah kamar 1.178 buah), Bintang 3 sebanyak 19 Hotel (jumlah kamar 1.737 buah), Bintang 2 sebanyak 13 Hotel (jumlah kamar 648 buah), dan Bintang 1 sebanyak 9 Hotel (jumlah kamar 397 buah). Adapun jumlah Hotel Non Bintang di DIY tahun 2015 sebanyak 561 Hotel dengan jumlah kamar sebanyak 10.963 (belum termasuk Pondok Wisata).

Pada tahun 2016, jumlah Hotel Bintang di DIY yang bersertifikasi menurun menjadi 54 Hotel dengan jumlah kamar 5460 yang terdiri dari Bintang 5 sebanyak 7 Hotel (jumlah kamar 1.533 buah), Bintang 4 sebanyak 14 Hotel (jumlah kamar 3.801 buah), Bintang 3 sebanyak 17 Hotel (jumlah kamar 1.631 buah), Bintang 2 sebanyak 5 Hotel (jumlah kamar 232

adalah alat pemasaran yang baik yaitu seperangkat produk, harga, promosi, distribusi, yang dikombinasikan untuk menghasilkan respon yang diinginkan dari target pasar.

Salah satu usaha hotel yang dekat dengan pusat pemerintahan Yogyakarta yaitu Hotel Galuh Anindita Yogyakarta. Hotel Galuh Anindita adalah hotel non bintang yang berlokasi strategis di tengah kota Yogyakarta. Galuh Anindita Yogya hanya 10 menit berkendara menuju Malioboro, Kraton Jogja dan Tugu Yogyakarta, 20 menit berkendara ke Bandara Adi Sutjipto, dan berjalan ke Rumah Sakit Bethesda, Panti Rapih dan Dr Yap Hospital. Hotel Galuh Anindita memiliki 4 tipe kamar yaitu Melati, Standar, Deluxe dan Deluxe Family. Sebagai hotel non bintang yang terletak tidak jauh dari pusat pariwisata Yogyakarta, tentunya tantangan lebih besar sehingga harus memiliki keunggulankeunggulan dibanding hotel lain yang sejenis untuk mendapatkan sale yang diharapkan. Berdasarkan uraian di atas maka peneliti tertarik untuk mengetahui pengaruh bauran pemasaran yang dilakukan Hotel Galuh Anindita terhadap sale-nya.
\end{abstract} buah), dan Bintang 1 sebanyak 9 Hotel (jumlah kamar 397 buah). Jumlah Hotel Non Bintang di DIY tahun 2016 juga menurun menjadi 521 Hotel dengan jumlah kamar sebanyak 9963 (belum termasuk Pondok Wisata).

Pada tahun 2017, Jumlah Hotel Bintang di DIY tahun 2016 yang bersertifikasi sebanyak 96 Hotel dengan jumlah kamar 9.224 yang terdiri dari Bintang 5 sebanyak 9 Hotel (jumlah kamar 1.873 buah), Bintang 4 sebanyak 18 Hotel (jumlah kamar 2.516 buah), Bintang 3 sebanyak 32 Hotel (jumlah kamar 2.756 buah), Bintang 2 sebanyak 24 Hotel (jumlah kamar 1.538 buah), dan Bintang 1 sebanyak 13 Hotel (jumlah kamar 541). Jumlah Hotel Non Bintang di DIY tahun 2017 sebanyak 589 Hotel dengan jumlah kamar sebanyak 10.376 (belum termasuk Pondok Wisata).

Berdasarkan data di atas, jumlah hotel yang meningkat pesat di tahun 2017 menunjukkan bahwa usaha perhotelan semakin berkembang, sehingga persaingan semakin ketat. Persaingan yang ketat membutuhkan keunggulan-keunggulan hotel untuk mencapai penjualan yang ditargetkan. Hotel sebagai usaha jasa memerlukan bauran pemasaran untuk mencapai sale yang ditargetkan. Kotler dan Armstrong (2012: 92) mengemukakan bahwa bauran pemasaran

\subsection{Kajian Teori}

\subsubsection{Industri Perhotelan}

Ismayanti (2010: 125) mengemukakan pertumbuhan sarana akomodasi dapat bersifat memenuhi permintaan pasar yang sudah nyata, tetapi dapat juga merupakan antisipasi.Pembangunan sarana akomodasi tidak dapat lepas dari jumlah wisatawan yang berkunjung ke suatu daerah tujuan wisata karena mempengaruhi kelangsungan hidup usaha sarana akomodasi itubergantung.

Dalam Peraturan Menteri Pariwisata dan Ekonomi Kreatif Republik Indonesia Nomor PM.53/HM.001/MPEK/2013 Tentang Standar Usaha Hotel disebutkan bahwa usaha hotel adalah usaha penyediaan akomodasi berupa kamar-kamar dalam suatu bangunan, yang dapat dilengkapi dengan jasa pelayanan makan dan minum, kegiatan hiburan dan/atau fasilitas lainnya secara harian dengan tujuan memperoleh keuntungan.

Menurut Ismayanti (2010: 135-138) usaha hotel dibagi menjadi 6 yaitu Inn atauhotel, motel, resort, pondok wisata, losmen, dan cottage.Sofyan (2011: 59) mengemukakan bahwa kegiatan usaha hotel meliputi penyediaan kamar tempat menginap, penyediaan tempat pelayanan makan dan minum, pelayanan pencucian pakaian/binatu, 
dan penyediaan fasilitas akomodasi dan pelayanan lain, yang diperlukan bagi penyelenggara kegiatan usaha hotel.

Hubungan industri perhotelan dan kepariwisataan memiliki kaitan yang erat. Hotel termasuk sarana pokok kepariwisataan (main tourism superstructures) yang berarti hidup dan kehidupannya banyak tergantung wisatawan yang datang (Oktariani, 2016: 48). Menurut Ismayanti (2010: 25), hotel juga menentukan perkembangan dunia pariwisata di kota setempat. Tanpa adanya akomodasi pariwisata yang memadai, maka industri pariwisata akan mengalami kesulitan dalam perkembangannya. Keberadaan hotel juga terkadang menjadi tolak ukur akan tingkat dan kualitas pariwisata setempat, sehingga tentunya mempengaruhi pendapatan daerah di segi pariwisata.

\subsubsection{Bauran Pemasaran Perusahaan Jasa}

Industri perhotelan termasuk dalam jasa. Rangkuti (2006: 26) mendefinisikan jasa sebagai pemberian suatu kinerja atau tindakan tidak kasat mata dari suatu pihak ke pihak lain. Pada umumnya jasa diproduksi dan dikonsumsi secara bersamaan sehingga interaksi antara pemberi dengan penerima jasa saling mempengaruhi hasil jasa tersebut. Menurut Kotler yang dikutip Lupiyoadi (2006: $6)$, jasa adalah setiap tindakan atau kegiatan yang dapat ditawarkan oleh satu pihak kepada pihak lain, pada dasarnya tidak berwujud dan tidak mengakibatkan perpindahan kepemilikan apapun. Produksi jasa mungkin berkaitan dengan produk fisik atau tidak. Berdasarkan uraian di atas, maka disimpulkan bahwa jasa adalah kegiatan ekonomi dengan hasil keluaran yang tidak berwujud yang ditawarkan dari penyedia jasa yaitu perusahaan kepada pengguna jasa atau konsumen.

Berdasarkan karakteristik jasa tersebut maka pemasaran produk jasa juga berbeda dengan pemasaran produk barang yang berwujud. Lupiyoadi (2006: 5) mengemukakan bahwa pemasaran jasa merupakan setiap tindakan yang ditawarkan oleh salah satu pihak kepada pihak lain yang secara prinsip intangible dan tidak menyebabkan perpindahan kepemilikan apapun. Umar (2003: 76) mendefinisikan pemasaran jasa sebagai pemasaran yang bersifat intangible dan immaterial dan dilakukan pada saat konsumen berhadapan dengan produsen. Lovelock \& Wright mendefinisikan pemasaran jasa sebagai bagian dari sistem jasa keseluruhan dimana perusahaan tersebut memiliki sebuah bentuk kontak dengan pelanggannya, mulai dari pengiklanan hingga penagihan, hal tersebut mencakup kontak yang dilakukan pada saat penyerahan jasa (Lovelock and Wright, 2007: 52).

\subsubsection{Sale (Penjualan)}

Nafarin (2009: 166) mendefinisikan penjualan sebagai proses kegiatan menjual, yaitu dari kegiatan penetapan harga jual sampai produk yang didistribusikan ke tangan konsumen (pembeli). Assauri (2011: 23) mendefinisikan kegiatan penjualan merupakan kegiatan pelengkap atau suplemen dari pembelian, untuk memungkinkan terjadinya transaksi. Jadi kegiatan pembelian dan penjualan merupakan satu kesatuan untuk dapat terlaksananya transfer hak atau transaksi. Oleh karena itu, kegiatan penjualan seperti halnya kegiatan pembelian, terdiri dari serangkaian kegiatan yang meliputi penciptaan permintaan, menemukan si pembeli, negosiasi harga, dan syarat-syarat pembayaran, dalam hal ini penjual harus menentukan kebijaksanaan dan prosedur yang akan diikuti yang memungkinkan dilaksanakannya rencana penjualan yang ditetapkan.

Dalam penjualan bidang industri perhotelan, standar telah ditentukan dalam Peraturan Menteri Pariwisata dan Ekonomi Kreatif Republik Indonesia Nomor PM.53/HM.001/MPEK/2013 Tentang Standar Usaha Hotel. Standar Usaha Hotel mencakup aspek produk, pelayanan, dan pengelolaan.

\subsection{Metode Penelitian}

Penelitian ini merupakan penelitian kuantitatif. Penelitian dilakukan di Hotel Galuh Anindita Yogyakarta pada bulan Mei-Juli 2019. Pengumpulan data dilakukan dengan angket, observasi, dan dokumentasi. Populasi penelitian adalah pengunjung yang check-in ke Hotel Galuh Anindita Yogyakarta. Pengambilan sampel diambil dengan menggunakan metode jenis incidental sampling, yaitu pengambilan sampel siapa saja yang ditemui yang dapat menjadi sampel. Teknik analisis data menggunakan analisis statistik deskriptif untuk menggambarkan karakteristik responden (pengunjung hotel) meliputi usia, jenis kelamin, pendidikan, pekerjaan, penghasilan, serta asal dan jumlah kunjungan dari setiap responden. Uji hipotesis menggunakan uji regresi linear.

\subsection{Hasil Dan Pembahasan Penelitian 4.1.1. Karakteristik Responden}

Responden dalam penelitian ini berdasarkan usia, jenis kelamin, pendidikan terakhir, jumlah kunjungan, asal provinsi, pekerjaan, dan penghasilan. 


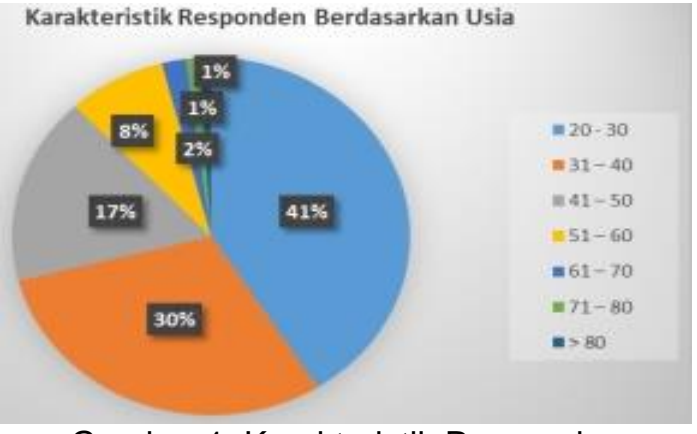

Gambar 1. Karakteristik Responden Berdasarkan Usia

Berdasarkan grafik pada Gambar 1 di atas maka dapat dilihat bahwa pengunjung Hotel Galuh Anindita Yogyakarta paling banyak usia 30 - 40 tahun yaitu 41 responden (41\%), dan jumlah terbanyak kedua yaitu pengunjung dengan usia 31-40 tahun sebanyak 30 responden (30\%).

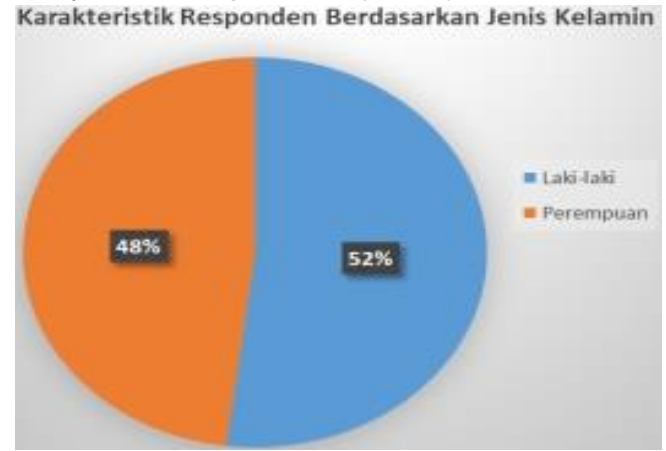

Gambar 2. Karakteristik Responden Berdasarkan Jenis Kelamin

Berdasarkan grafik pada Gambar 2 di atas, dapat dilihat bahwa responden paling banyak adalah laki-laki yaitu 52 orang (52\%) atau lebih dari separuh dari keseluruhan responden, sedangkan responden perempuan hanya 48 orang $(48 \%)$.

Karakteristik Responden Berdasarkan Pendidikan Terakhir

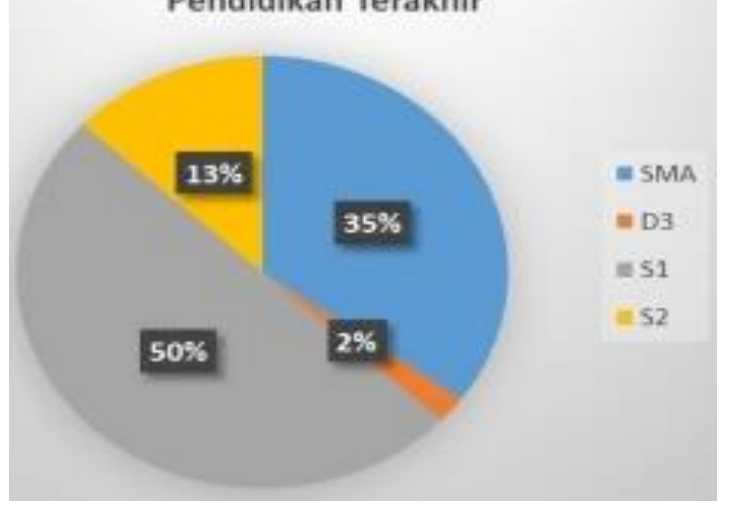

Gambar 3. Karakteristik Responden

Berdasarkan Pendidikan Terakhir

Berdasarkan grafik pada Gambar 3 di atas dapat dilihat bahwa pendidikan terakhir paling banyak adalah pendidikan perguruan tinggi, dengan tingkat terbanyak di S1 yaitu 50 $\%$ (separuh dari seluruh responden), S2 sebanyak $13 \%$, dan D3 sebanyak $2 \%$.

Karakteristik Responden Berdasarkan Jumlah Kunjungan

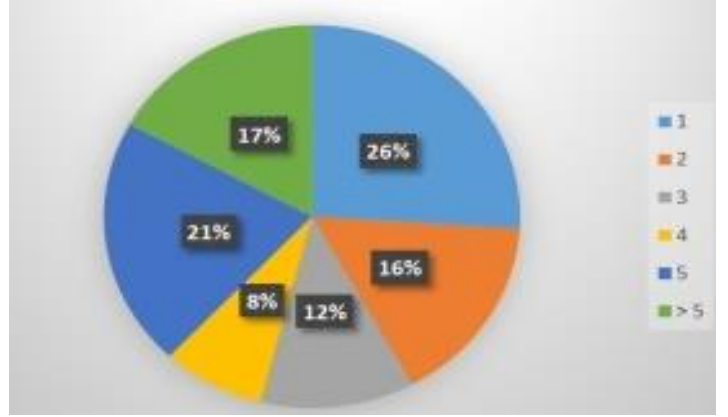

Gambar 4. Karakteristik Responden

Berdasarkan Jumlah Kunjungan

Berdasarkan grafik pada Gambar 4 di atas dapat dilihat bahwa sebagian besar sudah mengunjungi lebih dari 1 kali yaitu sebanyak 16 responden (16\%) dengan 2 kali kunjungan, 12 responden (12\%) dengan 3 kali kunjungan, 8 responden $(8 \%)$ dengan 4 kali kunjungan, 21 responden $(21 \%)$ dengan 5 kali kunjungan, dan lebih dari 5 kali kunjungan sebanyak 17 responden (17\%).

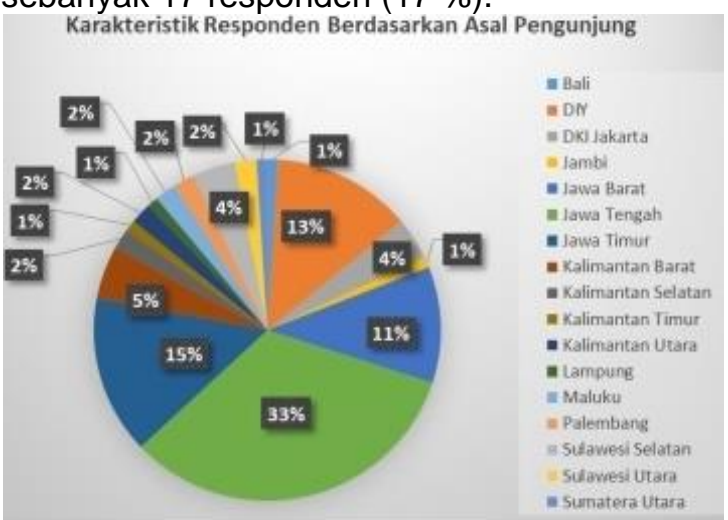

Gambar 5. Karakteristik Responden Berdasarkan Asal Pengunjung

Berdasarkan grafik pada Gambar 5 di atas dapat dilihat bahwa pengunjung paling banyak berasal dari Jawa Tengah yaitu $33 \%$, dan terbanyak kedua dari Jawa Timur (15\%) dan DIY (13\%), sedangkan pengunjung dari luar pulau Jawa masih sangat sedikit. 


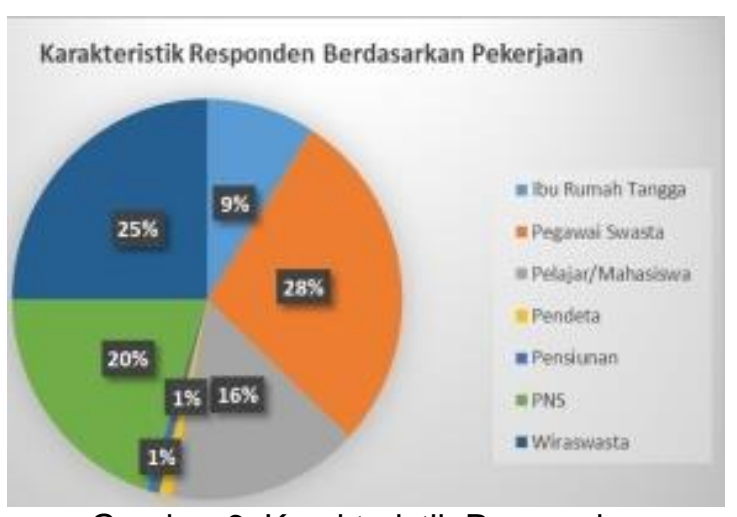

Gambar 6. Karakteristik Responden Berdasarkan Pekerjaan

Berdasarkan grafik pada Gambar 6 di atas dapat dilihat bahwa pengunjung hotel paling banyak yang berlatar belakang pekerjaan sebagai pegawai swasta $(28 \%)$, wiraswasta (25\%), dan PNS (20\%), sedangkan paling sedikit adalah pendeta dan pensiunan dengan jumlah masing-masing hanya $1 \%$.

Karakteristik Responden Berdasarkan Penghasilan

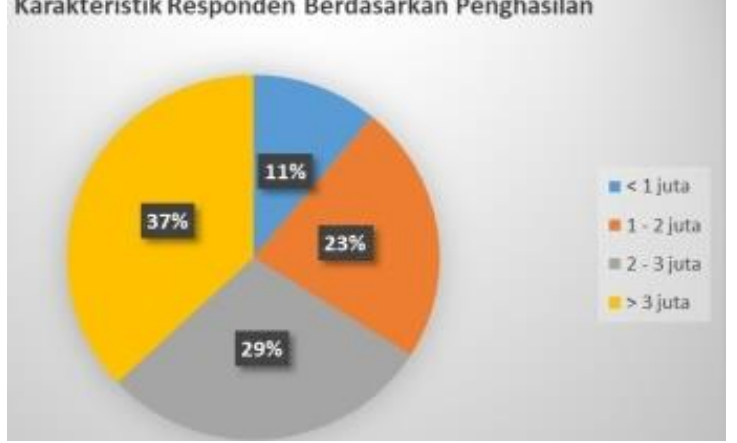

Gambar 7. Karakteristik Responden

Berdasarkan Penghasilan

Berdasarkan tabel dan grafik di atas dapat dilihat bahwa pengunjung hotel paling banyak berpenghasilan $>3$ juta yaitu sebanyak $37 \%$ dan responden dengan penghasilan $<1$ juta merupakan jumlah responden paling sedikit yaitu $11 \%$.

\subsubsection{Analisis Perhitungan}

Variabel dalam penelitian ini yaitu bauran pemasaran sebagai variabel bebas dan sale sebagai variabel terikat. Variabel bauran pemasarandiukur dengan 7 indikator yaitu Product (3 item), Price (3 item), Promotoion (4 item), Place (4 item), People (3 item), Process (3 item), dan Physical Evidence (5 item), sehingga total item tersebut berjumlah 21 item. Variabel salediukur dengan 3 aspek yaitu Aspek Product (3 item), Aspek Pelayanan(3 item), dan Aspek Pengelolaan(3 item), sehingga total item tersebut berjumlah 9 item. Keseluruhan item dinyatakan valid dan reliabel berdasarkan hasil perhitungan.

\section{Uji Korelasi}

Uji korelasi dilihat dari output regresi yaitu Descriptive statistic dan Correlation Berdasarkan hasil perhitungan dengan SPSS 25, hasil output diuraikan berikut ini:

Tabel 2.Descriptive Statistics

\begin{tabular}{|l|r|r|c|}
\hline \multicolumn{3}{|c|}{ Descriptive Statistics } \\
\hline & Mean & $\begin{array}{c}\text { Std. } \\
\text { Deviation }\end{array}$ & $\mathrm{N}$ \\
\hline Sale & 29.78 & 5.212 & 100 \\
\hline Bauran Pemasaran & 70.93 & 5.931 & 100 \\
\hline
\end{tabular}

Berdasarkan output pada Tabel 2di atas maka dapat dilihat bahwa rata-rata sale dan bauran pemasaran (jumlah data 100) adalah 29,78 dan 70,93, dapat disimpulkan bahwa rata-rata bauran pemasaran lebih tinggi daripada sale. Besarnya standar deviasi masing-masing variabel pada tabel 4.14 adalah 5,212 (variabel sale) dan 5,931 (variabel bauran pemasaran), artinya bahwa data variabel sale lebih homogeny daripada data bauran pemasaran.

Tabel 3. Correlations

\begin{tabular}{|l|l|r|r|}
\hline \multicolumn{4}{|c|}{ Correlations } \\
\hline \multicolumn{2}{|c|}{} & \multicolumn{1}{|c|}{ Sale } & \multicolumn{1}{c|}{$\begin{array}{c}\text { Bauran } \\
\text { Pemasaran }\end{array}$} \\
\hline $\begin{array}{l}\text { Pearson } \\
\text { Correlati } \\
\text { on }\end{array}$ & Sale & 1.000 & .728 \\
\cline { 2 - 4 } & $\begin{array}{l}\text { Bauran } \\
\text { Pemasaran }\end{array}$ & .728 & 1.000 \\
\hline $\begin{array}{l}\text { Sig. (1- } \\
\text { tailed) }\end{array}$ & Sale & & .000 \\
\cline { 2 - 4 } & $\begin{array}{l}\text { Bauran } \\
\text { Pemasaran }\end{array}$ & .000 &. \\
\hline N & Sale & 100 & 100 \\
\cline { 2 - 4 } & $\begin{array}{l}\text { Bauran } \\
\text { Pemasaran }\end{array}$ & 100 & 100 \\
\hline
\end{tabular}

Berdasarkan output pada Tabel 3di atas maka dapat dilihat bahwa besarnya nilai korelasi (r) antara variabel bauran pemasaran dengan sale menunjukkan angka positif sebesar 0,728 , ini memiliki makna bahwa kedua variabel berkorelasi positif artinya bahwa semakin meningkat bauran pemasaran yang dilakukan maka sale juga semakin meningkat (korelasi positif). Besarnya nilai adalah 0,728 maka nilai tersebut berdasarkan pedoman untuk memberikan interprestasi koefisien korelasi berada pada rentang 0,60 - 0,799 sehingga korelasi tergolong kuat. Nilai 1 dalam kolom variabel menunjukkan korelasi yang sempurna karena mengkorelasikan variabel yang sama (variabel bauran pemasaran dengan variabel sale). Peristiwa ini menunjukkan bahwa ketika variabel yang sama dikorelasikan maka hasilnya sempurna dengan nilai 1 atau tanpa eror. Nilai probabilitas (sig.two-tailed) adalah 0,000 , nilai ini lebih kecil dari 0,05 (asumsi tingkat kepercayaan $95 \%$ ), hal ini memiliki 
makna bahwa korelasi kedua variabel bersifat nyata atau $\mathrm{Ha}$ diterima dan $\mathrm{Ho}$ ditolak. Berdasarkan uji korelasi maka disimpulkan bahwa hubungan antara bauran pemasaran dengan sale dikategorikan kuat dengan nilai korelasi sebesar 0,728 .

\section{Uji Hipotesis}

Dalam penelitian ini, hipotesis disusun menjadi 2 yaitu $\mathrm{Ho}$ dan $\mathrm{Ha}$ dengan rumusan hipotesis sebagai berikut:

Ho : Tidak terdapat hubungan antara bauran pemasaran dengan sale di Hotel Galuh Anindita Yogyakarta

$\mathrm{Ha}$ : Terdapat hubungan antara bauran pemasaran dengan sale di Hotel Galuh Anindita Yogyakarta

Dengan kriteria sebagai berikut:

a. Nilai t hitung $<\mathrm{t}$ tabel, maka Hipotesis nol (Ho) diterima dan hipotesis alternatif $(\mathrm{Ha})$ ditolak.

b. Nilai t hitung $>\mathrm{t}$ tabel, maka Hipotesis nol $(\mathrm{Ho})$ ditolak dan hipotesis alternatif (Ha) diterima.

Atau dengan melihat signifikansi, yaitu:

a. Nilai probabilitas $\leq 0,05$ maka hipotesis nol (Ho) akan ditolak dan Hipotesis alternatif $(\mathrm{Ha})$ diterima.

b. Nilai probabilitas $>0,05$ maka hipotesis nol $(\mathrm{Ho})$ akan diterima dan Hipotesis alternatif $(\mathrm{Ha})$ ditolak.

Uji hipotesis dalam penelitian ini menggunakan uji regresi dengan output yang dapat dilihat pada Annova atau F Test dan Coefficient.

Tabel 4. F Test

\begin{tabular}{|l|r|r|r|r|r|}
\hline \multicolumn{7}{|c|}{ ANOVA $^{\text {S }}$} \\
Model & Squares & df & Square & F & Sig. \\
\hline 1 Regression & 1423.434 & 1 & 1423.434 & 110.211 & $.000^{\mathrm{b}}$ \\
\hline Residual & 1265.726 & 98 & 12.916 & & \\
\hline Total & 2689.160 & 99 & & & \\
\hline $\begin{array}{l}\text { a. Dependent Variable: Sale } \\
\text { b. Predictors: (Constant), Bauran Pemasaran }\end{array}$ & & \\
\hline
\end{tabular}

Berdasarkan Tabel 4di atas maka dapat dilihat bahwa uji Annova atau $\mathrm{F}$ Test menunjukkan besarnya $F$ hitung sebesar 110.211 dengan probabilitas signifikansi sebesar 0,000, artinya bahwa nilai ini < 0,05 sehingga disimpulkan bahwa model regresi dapat digunakan untuk memprediksi sale. Untuk mengetahui besarnya pengaruh variabel bauran pemasaran terhadap sale maka dapat dilihat pada tabel Model Summary berikut: Tabel 5.Model Summary

\begin{tabular}{|l|c|c|c|c|}
\hline \multicolumn{5}{|c|}{ Model Summary } \\
\hline & & $\begin{array}{c}\text { b } \\
\text { Model }\end{array}$ & $\begin{array}{c}\text { Adjusted } \\
\mathrm{R} \\
\text { Square }\end{array}$ & $\begin{array}{c}\text { Std. Error } \\
\text { of the } \\
\text { Square }\end{array}$ \\
Estimate
\end{tabular}

\begin{tabular}{|l|r|r|r|c|}
\hline 1 & $.728^{\mathrm{a}}$ & .529 & .525 & 3.594 \\
\hline \multicolumn{2}{|l|}{ a. Predictors: (Constant), Bauran Pemasaran } \\
\hline
\end{tabular}

Berdasarkan output pada Tabel 5di atas dapat dilihat bahwa uji $R$ square $\left(R^{2}\right)$ adalah 0,529 atau sebesar $52,9 \%$ bauran pemasaran menentukan sale. Nilai tersebut merupaka Koefisien Penentu (KP) atau koefisien determinasi, artinya bahwa kegiatan bauran pemasaran yang dilakukan oleh Hotel Galuh Anindita Yogyakarta tersebut memberikan kontribusi terhadap sale sebesar $52,9 \%$, sedangkan sisanya sebesar $47,1 \%$ sale ditentukan faktor lain yang tidak diteliti dalam penelitian ini. Berdasarkan koefisien determinasi tersebut maka dapat disimpulkan bahwa semakin kecil koefisien determinasi maka semakin lemah hubungan kedua variabel tersebut. Persamaan regresi dapat dilihat pada tabel Coefficient yang disajikan pada tabel berikut:

Tabel 6. Coefficient

\begin{tabular}{|c|c|c|c|c|c|}
\hline \multirow[b]{3}{*}{ Model } & \multicolumn{4}{|c|}{ Coefficients $^{\mathrm{a}}$} & \multirow[b]{3}{*}{ Sig. } \\
\hline & \multicolumn{2}{|c|}{$\begin{array}{c}\text { Unstandardized } \\
\text { Coefficients }\end{array}$} & \multirow{2}{*}{\begin{tabular}{|c|}
$\begin{array}{c}\text { Standardize } \\
\text { d } \\
\text { Coefficients }\end{array}$ \\
Beta \\
\end{tabular}} & \multirow[b]{2}{*}{$\mathrm{t}$} & \\
\hline & B & $\begin{array}{l}\text { Std. } \\
\text { Error }\end{array}$ & & & \\
\hline 1 (Constant) & -15.567 & 4.334 & & -3.592 & .001 \\
\hline $\begin{array}{l}\text { Bauran } \\
\text { Pemasaran }\end{array}$ & .639 & .061 & .728 & 10.498 & .000 \\
\hline
\end{tabular}

Berdasarkan Tabel 6 di atas maka persamaan regresi dapat disusun berdasarkan nilai koefisien yang dapat dilihat pada kolom B (Unstandardized Coefficients) sehingga terbentuk persamaan regresi linier sebagai berikut:

$Y=a+\beta X$

$Y=-15,567+0,639 X$

Persamaan di atas menunjukkan bahwa $Y$ merupakan variabel terikat (sale) dan $X$ merupakan variabel bebas (bauran pemasaran).

Dari persamaan di atas dapat disimpulkan pengaruh antara variabel bauran pemasaran $(\mathrm{X})$ terhadap sale $(\mathrm{Y})$, yaitu:

1. Konstanta sebesar - 15,567 menyatakan bahwa jika tidak ada bauran pemasaran maka sale-15,567.

2. Koefisien garis regresi sebesar 0,639 menyatakan bahwa setiap penambahan satu satuan bauran pemasaran maka akan meningkatkan sale sebesar 0,639. Koefisien bernilai positif artinya terjadi hubungan positif antara bauran pemasaran dengan sale, semakin naik angka bauran pemasaran maka semakin 
meningkat sale.

Regresi sederhana dengan angka korelasi 0,728 adalah juga angka Standardized Coefficient (beta), sedangkan uji t sebesar 10,498 untuk menguji signifikansi konstanta dan variabel dependen/bebas (sale)

Berdasarkan hipotesis yang dikemukakan di bagian terdahulu maka dapat dilakukan pengambilan keputusan sebagai berikut:

1. Berdasarkan nilai $t$ sebesar 10,498 (nilai $t$ ini sebagai $t$ hitung), sedangkan nilai $t$ tabel pada tingkat kepercayaan sebesar $95 \%$ dan df (degree of freedom) sebesar 98 (n-2 atau 100-2) yaitu 0,195. Berdasarkan nilai $t$ hitung dan $t$ tabel tersebut maka t hitung $>\mathrm{t}$ tabel $(10,498>$ $0,195)$ sehingga secara statistik terdapat korelasi signifikan antara variabel bauran pemasaran dengan sale sehingga $\mathrm{Ho}$ ditolak.

2. Besarnya nilai probabilitas (signifikansi) untuk uji dua sisi yaitu 0,000 sehingga nilai probabilitas kurang dari 0,05 $(0,000<$ $0,05)$. Berdasarkan nilai probabilitas tersebut maka disimpulkan bahwa Ho ditolak.

3. Keputusan yang dapat diambil yaitu Ho ditolak dan $\mathrm{Ha}$ diterima, artinya terjadi korelasi yang signifikan antara variabel bauran pemasaran dengan sale (sale secara signifikan disebabkan oleh kenaikan kegiatan bauran pemasaran) di Hotel Galuh Anindita Yogyakarta.

Berdasarkan uji hipotesis di atas maka dapat disimpulkan bahwa bauran pemasaran berpengaruh secara signifikan terhadap sale yang ditunjukkan dengan nilai probabilitas $0,000(<0,05)$ dan t sebesar 10,498. Besarnya pengaruh bauran pemasaran terhadap sale sebesar $52,9 \%$.

Seperti dikemukakan oleh Nafarin (2009: 166) bahwa penjualan sebagai proses kegiatan menjual, yaitu dari kegiatan penetapan harga jual sampai produk yang didistribusikan ke tangan konsumen (pembeli). Berdasarkan definisi tersebut, di hotel Galuh Anindita Yogyakarta juga terjadi proses jual beli berupa produk jasa. Penilaian kepuasan dalam produk berupa jasa memiliki subyektifitas karena masing-masing pengunjung memiliki penilaian berdasarkan pengalaman pribadi. Hal ini sangat penting diperhatikan oleh owner suatu perusahaan jasa seperti hotel Galuh Anindita Yogyakarta.

\subsection{Kesimpulan}

Perhitungan uji instrumen menggunakan validitas dan reliabilitas menunjukkan bahwa seluruh item dinyatakan valid dan reliabel sehingga dapat digunakan untuk analisis perhitungan. Berdasarkan hasil uji korelasi disimpulkan bahwa hubungan antara bauran pemasaran dengan sale dikategorikan kuat dengan nilai korelasi sebesar 0,728 . Uji hipotesis menunjukkan bahwa bauran pemasaran berpengaruh secara signifikan terhadap sale yang ditunjukkan dengan nilai probabilitas sebesar $0,000(<0,05)$ dan $t$ sebesar 10,498. Besarnya pengaruh bauran pemasaran terhadap sale sebesar 52,9\%. Berdasarkan hal tersebut maka disimpulkan bahwa Ho ditolak dan Ha diterima.

\section{Daftar Pustaka}

[1] Assauri, S. 2011. Manajemen Pemasaran Dasar, Konsep, dan Strategi. Jakarta: Grafindo Persada

[2] Ismayanti. 2010. Pengantar Pariwisata. Jakarta: PT Gramedia Widisarana. Indonesia.

[3] Kotler, Philip and Gary Armstrong. 2012. Prinsip-prinsip Pemasaran. Jakarta: Erlangga

[4] Lovelock, C. dan Lauren K Wright. 2007. Manajemen Pemasaran Jasa. Jakarta: PT. Indeks

[5] Lupiyoadi, H. 2006. Manajemen Pemasaran Jasa. Edisi Kedua. Jakarta: Penerbit Salemba

[6] Nafarin, M. 2009. Penganggaran Perusahaan. Edisi 3. Jakarta: Salemba Empat.

[7] Peraturan Menteri Pariwisata dan Ekonomi Kreatif Republik Indonesia Nomor PM.53/HM.001/MPEK/2013 Tentang Standar Usaha Hotel

[8] Rangkuti, F. 2009. Strategi Promosi yang Kreatif dan Analisis. Kasus. Integrated Marketing Communication. Jakarta : PT. GramediaPustakaUtama

[9] Sofyan. 2011. Manajemen Pemasaran Dasar, Konsep, dan strategi. Jakarta: PT. Grafindopersada.

Sumber lain:

[10] https://visitingjogja.com 